\title{
Analyzing the Influence of User-Generated-Content (UGC) on Social Media Platforms in Travel Planning
}

\author{
Sheetal Rathore ${ }^{\mathrm{A}}$ \\ Received: December 2019 | Accepted: July 2020 \\ DOI: $10.5937 /$ turizam24-24429
}

\begin{abstract}
In recent years Social Media (SM) platforms are becoming highly significant for the tourism industry as a medium for information exchange and communication platforms for tourists and travelers. Tourists are using Web 2.0 platforms to plan their travel, book hotels, confirm and cancel reservations, enquire about packages and itineraries, to read reviews posted by other travelers, and also to share their travel experiences by posting reviews, comments, ratings, photographs, etc. with others. The purpose of this study is to determine the influence of user-generated-contents on social media platforms in the travel planning of tourists in Udaipur, India. This study analyze the opinion of tourists regarding the benefits of social media and travel material posted on various social media platforms and to draw factors that are helpful in influencing the use of information through social media. To fulfill the objectives, primary data was collected by using a judgmental sampling method and a 5-point Likert type scale through a structured questionnaire. A sample of 309 respondents who visited Udaipur as a tourist during the period of early October 2017 to the end of March 2018 was surveyed. Using descriptive statistics and factor analysis results were presented and explained. The findings revealed that tourists have a positive opinion towards online reviews and travel material posted on social sites. The majority of the tourist respondents opined that online reviews, ratings, and comments, etc. regarding travel destinations, hotels, food, and climate, etc. help in their travel planning and travel related decisions. The results of factor analyses demonstrated that three factors namely; social media ease and trust, social media risk reduction and helpfulness and social media enhance joy and excitement were considered helpful in influencing the use of information through social media sites.
\end{abstract}

Keywords: Social Media; Destination; Web 2.0 platforms; User-Generated-Content (UGC); Travel Marketers.

A Mohanlal Sukhadia University, College of Commerce and Management Studies, Department of Business Administration, Saraswati Marg, Shiv Park Colony, Kumharon Ka Bhatta, Rajasthan Udaipur 313001, India; Corresponding author: jhala.sheetal@gmail.com 


\section{Introduction}

Nowadays, travel has become an information-intensive industry that makes travelers enable to have access information easily through the internet (Qu, Lee, 2011). The rise of social media has increasingly important for modern travel consumers. Earlier researches reveal the influence of social media and information and communication technologies on travel. Rathore and Narendran (2019) stated that tourist considers social media as a helpful and reliable source to get information about travel and this media is bringing change to search and selection pattern of travelers. Social media is a powerful tool and intensively used before planning a trip. Osei and Abenyin (2016) identify that social media is used at all stages of decision-making process by tourists but predominately used at need awareness stage and further it was found in the study that use of social media at evaluation and purchase stage has a positive influence on traveler's decision to travel.

Today, websites containing travelers' feedback and comments are becoming popular. Thus, many researchers have considered the significant role of such websites in the travel planning process (Lo et al., 2011; Huang, 2012). Hua et al., (2017) in their research signified the focus on online content as the factors in the development of marketing and communication strategies by tourist organizations which can influence the tourist decision-making process. Dina and Sabou (2012) perform research on Romanian 123 young people to identify the influence of social media while choosing tourist destinations. It was identified by the researcher that Romanian young people trust online information. Similarly, Faria and Elliot (2012) concluded in their study that the opinion of other travelers on social media plays a vital role in destination marketing.

\section{Literature review}

\section{Social media, web 2.0 and user-generated-content (ugc) concept}

Social media has evolved in the very new way in which people interact socially, by integrating critical information as well as communication technology, (mobile and virtual technologies) social interaction, and the construction of words, pictures, videos and audio (Zeng, 2013). There are several benefits associate with the use of social media for any business. Considering that social media is cost effective and bias-free, it represents an advantage over marketing communications (Kotler et al., 2010).

The term "web 2.o" is generally affiliated with an online community that encourages interactive information sharing, interoperability, user-centered design, and collaboration on the world-wide-web (O'Reilly, 2005). "Web 2.0 is the business revolution in the computer industry caused by the move to the internet as platform, and an attempt to understand the rules for success on that new platform. Chief among those rules is this: Build applications that harness network effects to get better the more people use them" (O’Reilly, 2006). Kaplan and Haenlein (2010) define User Generated Content (UGC) as "The sum of all the ways in which people make use of social media, usually applied to describe the various forms of media content that are publically available and created by end users"(p. 61). User-Generated-Content (UGC) such as blogs, reviews, experiences, opinions, posts, social networks, pictures, and videos, etc. are available on social sites for the benefit of prospective travelers. 


\section{Social media and tourism}

Social media adoption benefits both tourists and travel agents. Both tourists and travel agents perceived social media as a useful marketing tool (Abou-Shouk, Hewedi, 2016). Social media is changing the way tourist and travelers search, find, read, trust, and produce information about destinations. The social media plays an increasingly important role in several aspects of tourism, primarily in information searching, decision and selection making behavior process (Fotis et al., 2012), as well as in tourism promotion that focuses on best practices for interacting with the consumers via social media channels. Nezakati et al., (2015) identify that social media promote the knowledge sharing process in the tourism industry. Therefore, tourism enterprises are searching for new ways to make sense of social media and manage it to their advantage. Social media help travelers to search, organize, and share their travel memories and experiences through blogs (e.g., Blogger and Twitter), online social networks (e.g., Facebook, RenRen, and Trip Advisor), media sharing websites (e.g., Flickr and YouTube), social bookmarking websites (e.g., Delicious) and other ways (Leung et al., 2013).

Social media are playing an increasingly important role in online travel related information search. In research conducted by Xiang and Gretzel (2010) it was found that search engine, directly and indirectly, promote social media in traveler's information search. Social media websites appear on different search results pages of Google likely to direct travelers to social sites. The study further reveals that traditional marketers are facing challenges from social media websites such as trip advisors, virtual tourists an IgoUgo. Researchers concluded that social media constitute a substantial part of the online tourism domain and play an important role in travel planning using a search engine. Although tourists contribute free of charge to social media platforms, shared information may have high commercial value. Trip Advisor and similar review websites benefit from tourists' emerging communities by exploiting their user-generated contributions commercially (Munar, Jacobsen, 2013).

\section{Travel planning and user-generated-contents on social media}

Travel planning is a challenging task for any individual due to the high risk involved in visiting an unfamiliar destination. In order to reduce such risk and uncertainty, they try to collect more detailed and indispensable information about travel. Travelers many times regarded social media as a trustworthy source that could lower the perceived risk as well as uncertainty through their travel. The travel planning process would be increasingly influenced by electronic word-of-mouth from social media (Pan et al., 2007). A large percentage of travelers read other travelers' reviews in the process of trip planning (Gretzel, Yoo, 2008). Online user-generated reviews are a powerful marketing tool and can provide a competitive advantage due to its possible impact on the travel decision-making process (Zarrad, Debabi, 2015). Fotis et al. (2012) examined that user-generated-contents are trusted more than official tourism websites, travel agents, and advertising. In the research conducted by Duguay et al. (2015) it was found that opinions and posted contents of friends and family remain the most influential element of travel planning and booking. Chung et al., (2015) have studied travel information adoption of UGC on social media and found social media as a persuasive tool for travel information adoption. Research conducted by Gretzel et al. (2007) found that online review readers perceive online reviews enjoyable, up to date, and reliable compared to the travel service providers. The comprehensive review of literature depicts the influence of social media on travel planning at the international level, although there has not been identified any such research in 
India. Therefore, the need arises to understand and study the influence of user-generated-content being posted on social media platforms on travel planning in India. The research was conducted in Udaipur city which is popularly known to be one of the most popular tourist destinations of India. The results of this study will provide tourism marketing organizations to reach their customers with innovative promotion and communication tools of social media. This will also help in adopting the appropriate approach and adequately implementing social media marketing strategies.

\section{Research Objective}

Specifically, the study sought to achieve the following objectives:

- To analyze the influence of user-generated-content posted on social media sites in the travel planning of tourists.

- To examine the opinion of tourists regarding various benefits of social media and UGC on Web 2.0 platforms.

- To determine factors that are helpful in influencing the use of information through social media platforms.

\section{Methodology}

The data of the study based mainly on primary research conducted by taking responses from the tourists who had visited Udaipur during the period of early October 2017 to the end of March 2018. The tool used for the collection of data through the primary source was a pre-tested questionnaire. The questionnaire was prepared in English by taking help from the study by Gretzel \& Yoo (2008) and a review of literature from a wide range of peer-reviewed papers relating to the study. Few statements relating to the influence and use of other traveler's online reviews were taken from Gretzel and Yoo (2008) research paper. The questionnaire consists of diverse questions that include questions related to the demographic profile of the respondents, the influence of social media on travel planning, and the impact of social media and UGC on travelers through measurements of a five-point Likert-type scale. For the collection of secondary data number of sources was referred, and these include Science Direct, Springer, Wiley, Sage, Taylor and Francis, Google Scholar, SSRN, and Emerald.

The research is based on the non-probability sampling technique and the sampling method followed was judgmental sampling. As the survey was for only those tourists who are using social media an opening screening question was asked so as to recognize tourists in the target category. Researcher judgment was used to select potential respondents for smoothly conducting the sample survey. Tourists were contacted by visiting tourist places, sites, hotels, emporium, etc. inside the city, and responses were taken. During the survey period data was collected from 309 tourist respondents which include domestic and foreign tourists. Collected data were analyzed using SPSS software with the help of statistical tools such as descriptive statistics tools and multivariate technique Factor analysis for factor extraction. Pre-testing of the draft survey questionnaire was done to determine if there was a necessity for the improvisation of the initial questionnaire in terms of design, wording, statements, layout, technical jargon, omission, misunderstanding, etc. With few changes the final questionnaire was developed. Similarly pilot testing of 100 questionnaires was also done to check the reliability of the 
questionnaire. The reliability construct used in the questionnaire survey has been evaluated through internal consistency reliability measure Cronbach's alpha. Cronbach's alpha of the scale was $\alpha=0.895$.

\section{Results and discussion}

The socio-demographic characteristic of tourist respondents who have visited Udaipur has been measured through age, gender, nationality, occupation, and monthly income. From Table 1 it can be inferred that in age categories respondents aged between $26-35$ years with 38.51 percent dominated, which is followed by those aged 16-25 years with 17.48 percent. This implies that youth are more attracted to the use of social media for tourism purposes. Female users 51 percent are slightly more than male participants 49 percent and this underlines the equally important role of both male and female travelers and both are equally active on social media platforms. Among the tourist traveled to Udaipur around 52 percent of respondents were Indian and 48 percent were foreigners. This means that India is opening up for domestic tourism and foreign tourists also prefer to choose India as a travel destination.

From the sample of 309 tourists' social media users, around 29 percent of respondents were employed in private sector jobs. Professional practitioners and homemaker stood out amongst the least representations of the occupation category. This implies private sector employees prefer to travel more compared to people in any other occupational category, they are fond of traveling. Income category disclosed monthly income of Indian tourist's respondent only. It indicates that 29 percent of the respondents had an average monthly income of more than 75000 rupees followed by 22.50 percent respondent with monthly income up to 25000 rupees. This means that both the high and low-income group prefers to travel to Udaipur; the city is been appealing to all tourists with varying income.

Table1. Demographic characteristics of 309 tourists (Age, Gender, Nationality, Occupation and Monthly Income)

\begin{tabular}{|c|c|c|c|}
\hline \multicolumn{2}{|c|}{ Demographic characteristics } & $\begin{array}{l}\text { Frequency } \\
\text { (N) }\end{array}$ & $\begin{array}{c}\text { Percentage } \\
\text { (\%) }\end{array}$ \\
\hline Age & $\begin{array}{c}16-25 \\
26-35 \\
36-45 \\
46-55 \\
56-65 \\
\text { Above } 65\end{array}$ & $\begin{array}{r}54 \\
119 \\
40 \\
38 \\
35 \\
23\end{array}$ & $\begin{array}{c}17.48 \\
38.51 \\
12.94 \\
12.30 \\
11.33 \\
7.44\end{array}$ \\
\hline Gender & $\begin{array}{l}\text { Male } \\
\text { Female }\end{array}$ & $\begin{array}{l}150 \\
159\end{array}$ & $\begin{array}{l}48.54 \\
51.46\end{array}$ \\
\hline Nationality & $\begin{array}{l}\text { Indian } \\
\text { Foreigner }\end{array}$ & $\begin{array}{l}160 \\
149\end{array}$ & $\begin{array}{l}51.78 \\
48.22\end{array}$ \\
\hline \multirow{6}{*}{ Occupation } & Service (Private Sector) & 89 & 28.80 \\
\hline & Service (Govt. Sector) & 32 & 10.36 \\
\hline & Business & 33 & 10.68 \\
\hline & Unemployed & 34 & 11.00 \\
\hline & Professional Practice & 17 & 5.50 \\
\hline & Homemaker & 23 & 7.44 \\
\hline
\end{tabular}




\begin{tabular}{|c|c|c|c|}
\hline \multicolumn{2}{|c|}{ Demographic characteristics } & $\begin{array}{c}\text { Frequency } \\
(\mathrm{N})\end{array}$ & $\begin{array}{c}\text { Percentage } \\
(\%)\end{array}$ \\
\hline \multirow{3}{*}{\begin{tabular}{c} 
Occupation \\
\cline { 2 - 4 }
\end{tabular}} & Student & 44 & 14.24 \\
\hline \multirow{4}{*}{$\begin{array}{c}\text { Monthly Income } \\
\text { (In Rs.) }\end{array}$} & Retired & 37 & 11.97 \\
\cline { 2 - 4 } & Up to 25,000 & 36 & 22.50 \\
\cline { 2 - 4 } & $25,001-35,000$ & 9 & 5.63 \\
\cline { 2 - 4 } & $35,001-45,000$ & 23 & 14.38 \\
\cline { 2 - 4 } & $45,001-55,000$ & 11 & 6.88 \\
\cline { 2 - 4 } & $55,001-65,000$ & 9 & 5.63 \\
\cline { 2 - 4 } & $65,001-75,000$ & 17 & 10.63 \\
\cline { 2 - 4 } & Above 75,000 & 46 & 28.75 \\
\hline
\end{tabular}

Source: Researcher's Own

This section of the paper deals with the primary objective of the study regarding the influence user-generated-contents in the form of reviews, comments, ratings, photographs, video, etc. on social media on tourist travel planning. Table 2 represents the opinion of the respondents towards social media content on their trip planning. The table below shows that 15.86 percent of the respondents agree that social media influence their trip planning to a great extent. The cumulative percentage reveals that 68.93 percent of respondents feel that social media have an influence on their travel planning. The overall mean score of 3.15 also indicates that UGC on social media has a great influence. It means that respondents agree that social media influenced their travel plans.

Table 2. Extent of Influence of Social Media on Travel Planning

\begin{tabular}{|l|c|c|c|}
\hline Response & N & $\%$ & Cum. \% \\
\hline Influence a lot & 49 & 15.86 & 15.86 \\
\hline Moderately high influence & 98 & 31.72 & 47.57 \\
\hline Some influence & 66 & 21.36 & 68.93 \\
\hline Not much influence & 41 & 13.27 & 82.20 \\
\hline No influence at all & 55 & 17.80 & 100.00 \\
\hline Total & 309 & 100.00 & - \\
\hline \multicolumn{2}{|c|}{ Overall Mean $=3.15 ;$ SD $=1.33$} \\
\hline
\end{tabular}

Source: Researcher's Own

To examine the opinion of tourists regarding various benefits of social media and UGC on Web 2.o platforms, 21 statements based on review of literature were taken. Respondents were asked to indicate their preference on a five-point Likert scale that ranged through 1-5 from 1 being 'strongly disagree' to 5 being 'strongly agree'. Table 3 presents the basic benefits taken into consideration in measuring the influence of social media for travel-related decisions. The result of descriptive analysis disclosed that tourists have a positive opinion towards social media and UGC on social sites. The overall mean score of 3.74 indicates that respondent has a positive opinion towards online reviews and travel information posted on social sites. This implies that respondents consider this information helpful in travel planning. General under- 
standings of this analysis indicate that the tourists have a great influence on UGC. Thus, the positive inclination towards UGC indicates that there is a favorable influence of social media for various travel related decisions and help in travel planning.

Table 3. Opinion Regarding Benefits of Social Media and UGC on Social Sites

\begin{tabular}{|c|c|c|c|c|c|}
\hline Item & $\mathrm{N} \#$ & $\%$ & Mean & SD & Rank \\
\hline $\begin{array}{l}\text { Reviews on social media sites are good way to learn about travel } \\
\text { destinations }\end{array}$ & 235 & 76.05 & 4.03 & 0.87 & 1 \\
\hline $\begin{array}{l}\text { Using social media for travel purpose is popular because of } \\
\text { easiness of use of social media. }\end{array}$ & 213 & 68.93 & 3.94 & 0.83 & 2 \\
\hline Helps plan trips more effectively & 216 & 69.90 & 3.91 & 0.84 & 3 \\
\hline Using social media offers a variety of sources of information & 212 & 68.61 & 3.89 & 0.78 & 4 \\
\hline $\begin{array}{l}\text { While using social media for travel, the easiness of getting } \\
\text { information and extent to which the information is useful in } \\
\text { decision making process motivates the travelers }\end{array}$ & 212 & 68.61 & 3.88 & 0.79 & 5 \\
\hline Help making decision process easier & 206 & 66.67 & 3.86 & 0.83 & 6 \\
\hline Online reviews help avoid places/services you would not enjoy & 204 & 66.02 & 3.83 & 0.87 & 7 \\
\hline Online reviews help with evaluation of alternative & 202 & 65.37 & 3.81 & 0.86 & 8 \\
\hline $\begin{array}{l}\text { Increase confidence and help reduce risk by making it easier to } \\
\text { imagine what a place will be like }\end{array}$ & 199 & 64.40 & 3.81 & 0.88 & 8 \\
\hline Social media helps in information exchange on travel quickly & 196 & 63.43 & 3.79 & 0.84 & 10 \\
\hline Provides with new ideas & 186 & 60.19 & 3.74 & 0.90 & 11 \\
\hline $\begin{array}{l}\text { Peers' opinion and comments have significant influence on } \\
\text { destination choice }\end{array}$ & 185 & 59.87 & 3.72 & 0.94 & 12 \\
\hline Make me feel excited about travelling & 183 & 59.22 & 3.71 & 0.95 & 13 \\
\hline $\begin{array}{l}\text { People have more faith in social media as compared to } \\
\text { promotions on traditional advertising media }\end{array}$ & 187 & 60.52 & 3.70 & 0.87 & 14 \\
\hline Social media encourage interaction among travelers & 173 & 55.99 & 3.66 & 0.87 & 15 \\
\hline Helps me imagine my trip more vividly & 164 & 53.07 & 3.58 & 0.92 & 16 \\
\hline Reduce the likelihood of later regretting a decision & 154 & 49.84 & 3.58 & 0.87 & 17 \\
\hline $\begin{array}{l}\text { User generated contents are trusted more than official tourism } \\
\text { websites, travel agents and advertising }\end{array}$ & 152 & 49.19 & 3.54 & 0.99 & 18 \\
\hline $\begin{array}{l}\text { While using social media for travel purpose generates feeling of } \\
\text { pleasure }\end{array}$ & 151 & 48.87 & 3.54 & 0.92 & 19 \\
\hline Add fun to the travelling process & 145 & 46.93 & 3.52 & 0.96 & 20 \\
\hline Social media contacts are useful motivator for organizing a trip & 149 & 48.22 & 3.51 & 0.92 & 21 \\
\hline \multicolumn{6}{|c|}{$\begin{array}{c}\text { Overall Mean }=3.74 ; \text { S.D }=0.89 \\
\text { N\# (Strongly Agree \& Agree), N = } 309\end{array}$} \\
\hline
\end{tabular}

Source: Researcher's Own

Factor analysis was applied to identify the factors that are helpful in influencing the use of information through social media. Exploratory Factor analysis was used for data reduction and summarization. The influence of social media on travel planning was measured through a Likert five-point scale question comprising 21 items relating to the benefit of online reviews and other travel material posted on social media sites. 
Table 4 reveals the appropriateness of factor analysis in both tests. KMO statistics value depicted in the test is 0.939 which is greater than 0.50 . This indicates that data was large enough to proceed for factor analysis. Bartlett's test of sphericity examines whether the original correlation matrix is an identity matrix or not. P-value of less than 0.01 signifies the existence of no identity matrix at $1 \%$ level of significance. The below results show p-value $=0.000$ which is less than 0.01 , it is appropriate to use factor analysis.

Table 4. KMO and Barlett's Test of Sphericity

\begin{tabular}{|l|c|}
\hline Kaiser-Meyer-Olkin Measure of Sampling Adequacy & 0.939 \\
\hline Bartlett's Test of Sphericity & \\
Approx. Chi-Square & 3239.816 \\
Df & 210 \\
Sig. & 0.000 \\
\hline
\end{tabular}

Source: Researcher's Own

Table 5 shows the initial and extracted communality. A relatively small value of the extracted communalities suggests that a particular variable is a misfit for factor solution and can be dropped out from factor analysis. In the table two statements have a value less than 0.5 , the first statement is "Helps plan trips more effectively" and the second one is "Peers' opinion and comments have a significant influence on destination choice". Hence, these two items were dropped from factor analysis.

Table 5. Communalities

\begin{tabular}{|c|c|c|}
\hline & Initial & Extraction \\
\hline 1. Reviews on social media sites are good way to learn about travel destinations & 1.000 & 0.508 \\
\hline 2. Online reviews help with evaluation of alternative & 1.000 & 0.590 \\
\hline 3. Online reviews help avoid places/services you would not enjoy & 1.000 & 0.609 \\
\hline 4. Provides with new ideas & 1.000 & 0.582 \\
\hline 5. Increase confidence and help reduce risk by making it easier to imagine what a place will be like & 1.000 & 0.570 \\
\hline 6. Help making decision process easier & 1.000 & 0.648 \\
\hline 7. Reduce the likelihood of later regretting a decision & 1.000 & 0.547 \\
\hline 8. Helps plan trips more effectively & 1.000 & 0.454 \\
\hline 9. Make me feel excited about travelling & 1.000 & 0.668 \\
\hline 10. Add fun to the travelling process & 1.000 & 0.807 \\
\hline 11. Helps me imagine my trip more vividly & 1.000 & 0.714 \\
\hline 12. Social media contacts are useful motivator for organizing a trip & 1.000 & 0.578 \\
\hline $\begin{array}{l}\text { 13. User generated contents are trusted more than official tourism websites, travel agents and } \\
\text { advertising }\end{array}$ & 1.000 & 0.502 \\
\hline 14. Peers' opinion and comments have significant influence on destination choice & 1.000 & 0.409 \\
\hline 15. Social media helps in information exchange on travel quickly & 1.000 & 0.545 \\
\hline 16. Social media encourage interaction among travelers & 1.000 & 0.576 \\
\hline 17. People have more faith in social media as compared to promotions on traditional advertising media & 1.000 & 0.636 \\
\hline 18. Using social media offers a variety of sources of information & 1.000 & 0.571 \\
\hline
\end{tabular}




\begin{tabular}{|l|c|c|}
\hline & Initial & Extraction \\
\hline $\begin{array}{l}\text { 19. While using social media for travel, the easiness of getting information and extent to which the } \\
\text { information is useful in decision making process motivates the travelers }\end{array}$ & 1.000 & 0.556 \\
\hline 20. While using social media for travel purpose generates feeling of pleasure & 1.000 & 0.561 \\
\hline 21. Using social media for travel purpose is popular because of easiness of use of social media. & 1.000 & 0.522 \\
\hline
\end{tabular}

Source: Researcher's Own

Table 6 shows the total variance explained by three factors extracted using eigenvalue criteria. An eigenvalue of more than one was used for factor extraction. Using Principal Component Method (PCM) and varimax rotation it was found that in totality 58.83 percent of the variation in the initial 19 items was explained by extracted factors. This means that these three factors were influencing the use of information through social media by tourists.

Table 6. Total Variance Explained

\begin{tabular}{|c|c|c|c|c|c|c|}
\hline \multirow{2}{*}{ Component } & \multicolumn{3}{|c|}{ Initial Eigenvalues } & \multicolumn{3}{c|}{ Rotation Sums of Squared Loadings } \\
\cline { 2 - 7 } & Total & $\%$ of Variance & Cumulative \% & Total & $\%$ of Variance & Cumulative \% \\
\hline 1 & 8.36 & 44.00 & 44.00 & 4.05 & 21.31 & 21.31 \\
\hline 2 & 1.43 & 7.51 & 51.52 & 3.86 & 20.29 & 41.61 \\
\hline 3 & 1.39 & 7.31 & 58.83 & 3.27 & 17.22 & 58.83 \\
\hline
\end{tabular}

Source: Researcher's Own

Table 7 shows the rotated factor loading matrix. The columns in the table represent the factor loading for each item, for the concerning factor. The items which correlate greater than 0.5 with the particular factor are shown in a particular component column. Therefore, here only those factor loadings are shown in below table which shows correlation values greater than 0.5 of that particular item with a particular factor On applying factor analysis, the original 19 items are categorized into three factors, which were named according to their characteristics: Factor $1=$ Social media ease and trust; Factor $2=$ Social media risk reduction and helpfulness; Factor 3 = Social media enhance joy and excitement. So these three factors extracted are helpful in influencing the use of information through social media.

Table 7. Rotated Factor Loading Matrix

\begin{tabular}{|l|c|c|}
\hline \multirow{2}{*}{} & \multicolumn{2}{|c|}{ Component } \\
\cline { 2 - 3 } & $\mathbf{1}$ & $\mathbf{2}$ \\
\hline People have more faith in social media as compared to promotions on traditional advertising media & 0.764 & $\mathbf{3}$ \\
\hline Social media encourage interaction among travelers & 0.691 & \\
\hline Social media helps in information exchange on travel quickly & 0.688 & \\
\hline Using social media offers a variety of sources of information & 0.675 & \\
\hline Using social media for travel purpose is popular because of easiness of use of social media. & 0.645 & \\
\hline $\begin{array}{l}\text { While using social media for travel, the easiness of getting information and extent to which the } \\
\text { information is useful in decision making process motivates the travelers }\end{array}$ & 0.609 & \\
\hline $\begin{array}{l}\text { User generated contents are trusted more than official tourism websites, travel agents and } \\
\text { advertising }\end{array}$ & 0.525 & \\
\hline Online reviews help avoid places/services you would not enjoy & & \\
\hline
\end{tabular}




\begin{tabular}{|l|c|c|}
\hline & \multicolumn{2}{|c|}{ Component } \\
\cline { 2 - 3 } & 1 & 2 \\
\hline Online reviews help with evaluation of alternative & 0.746 & 3 \\
\hline Increase confidence and help reduce risk by making it easier to imagine what a place will be like & 0.704 & 0.634 \\
\hline Help making decision process easier & 0.630 & \\
\hline Reviews on social media sites are good way to learn about travel destinations & 0.616 & \\
\hline Provides with new ideas & & 0.593 \\
\hline Reduce the likelihood of later regretting a decision & & 0.837 \\
\hline Add fun to the travelling process & & 0.786 \\
\hline Helps me imagine my trip more vividly & & 0.758 \\
\hline Make me feel excited about travelling & & 0.584 \\
\hline Social media contacts are useful motivator for organizing a trip & & \\
\hline While using social media for travel purpose generates feeling of pleasure & & \\
\hline
\end{tabular}

Source: Researcher's Own

\section{Conclusion and recommendations}

The research results reported in this study show that the rise of social media has particularly significant implications for the travel and tourism industry. It can be concluded from the results that social media has a positive influence on travelers relating to travel decisions and planning. Tourists consider UGC on web 2.0 platforms a helpful source to gather information about travel and are using UGC for travel-related decisions. This is also consistent with Zarrad and Debabi (2015), findings which also revealed that online user-generated reviews are powerful marketing tools and can provide competitive advantage due to its possible impact on the traveler's decision-making process. Similarly Zivkovic et al. (2014) stated in their research that tourists are strongly influenced by social media as they use information posted on social media to affect their decision-making process especially travel decisions. Results of present study is consistent with Gretzel and Yoo (2008) study that age difference occurred across a variety of perception and use behavior of social media but presented some contradictory findings regarding female reaping greater benefits from social media than male. The findings of mean score evaluation of items of social media and UGC benefits exhibited that social media has been successful in creating influence for travel-related decisions. The overall high mean score justifies that respondents have a positive opinion towards social media and UGC on social sites. Tourists consider this information useful and helpful in their travel planning. All 21 items regarding the benefits of social media and UGC on social sites show positive evaluations, descriptive statistics results revealed that respondents consider reviews on social sites are a good way to learn about the travel destination. The results of this research study offer further evidence in support of earlier research conducted by Gretzel et al. (2007) that opinions posted on online travel review sites by other travelers were most sources of information frequently used by travelers. In the same manner, the respondents revealed their high agreement with the scale on ease of use of social media, help to plan trips effectively, provide a variety of information, help in taking decision, and evaluating alternative. Thus, the positive inclination towards UGC and social media benefits indicates that there is a favorable influence of social media for various travel related decisions and it helps in travel planning. 
Finally, a factor analysis result reveals that three factors namely; social media ease and trust, social media risk reduction and helpfulness and social media enhance joy and excitement play a significant role in influencing the use of information through social media platforms. These social media factors play a significant role in influencing consumer decisions concerning travel planning and the consumption of travel-related products. Result of this study consistent with Hua et al. (2017) study in which researchers identify factors which may influence consumer behavior to use social media as a tool to select tourist destination. The present study suggests tourism marketers should adopt social media as a tool of direct interaction with the consumers, for giving quick responses to their queries and concerns. Tourism firms can exploit UGC for improving services by analyzing travelers' post-trip experiences. The study suggested that tourism and travel marketers should spend more time on social media to identify consumers' comments and reviews regarding their experience to achieve a better understanding of their needs, desire, and requirements. Further, the study suggested that tourism firms should monitor reviews of social media users and react promptly and appropriately to take advantage of positive reviews and handle negative comments.

\section{References}

Abou-Shouk, M. A., Hewedi, M. M. 2016. Antecedents and consequences of social media adoption in travel and tourism: evidence from customers and industry. International Journal of Social, Behavioral, Educational, Economic, Business and Industrial Engineering 10(2), 652-659.

Chung, N., Han, H., Koo, C. 2015. Adoption of travel information in user-generated content on social media: The moderating effect of social presence. Behaviour \& Information Technology 34(9), 902-919.

Dina, R., Sabou, G. 2012. Influence of Social Media in Choice of Touristic Destination. Cactus Tourism Journal 3(2), 24-30.

Duguay, B., Haider, M., Boulard, D., Khomsi, M. R., Moca, I. 2015. Social Media Influences on Travel Planning and Booking. Revue de Management et de Strategie 12(1), 1-45. Retrieved on 24 June 2016 from https://www.revue-rms.fr/Influences-on-travel-planning-and-booking a115.html

Faria, W.L., Elliot, S. 2012. Understanding the Role of Social Media in Destination Marketing. Tourismos: An International Multidisciplinary Journal of Tourism 7(1), 193-211.

Fotis, J., Buhalis, D., Rossides, N. 2012. Social media use and impact during the travel planning process. Information and Communication Technologies in Tourism 13-24, Springer. Retrieved from https://link.springer. com/book/10.1007/978-3-7091-114.2-o

Gretzel, U., Yoo, K. H. 2008. Use and Impact of online travel reviews. Information and communication technology in tourism, 35-46, NewYork, Springer. Retrieved from https://www. researchgate.net/publication/221357282

Gretzel, U., Yoo, K. H., Purifoy, M. 2007. Online Travel Review study: Role and Impact of Online Travel Reviews. Laboratory for intelligent system in Tourism Texas A \& M University. URL: www.tripadvisor.com/pdfs/OnlineTravel ReviewReport.pdf

Hua, L. Y., Ramayah, T., Ping, T. A., Hwa, C. J. 2017. Social media as a tool to help select tourism destinations: The case of Malaysia. Information Systems Management 34(3), 265-279.

Huang, L. 2012. Social media as a new play in a marketing channel strategy: Evidence from Taiwan travel agencies' blogs. Asia Pacific Journal of Tourism Research 17(6), 615-634. 
Kaplan, A. M., Haenlein, M. 2010. Users of the world, unite! The challenges and opportunities of Social Media. Business Horizons 53(1), 59-68.

Kotler, P., Kartajaya, H., Setiawan, I. 2010. Marketing 3.o. John Wiley \& Sons, Inc, New Jersey. Leung, D., Law, R., VanHoof, H., Buhalis, D. 2013. Social media in tourism and hospitality: A literature review. Journal of Travel \& Tourism Marketing 30(1-2), 3-22.

Lo, I. S., McKercher, B., Lo, A., Cheung, C., Law, R. 2011. Tourism and online photography. Tourism management 32(4), 725-731.

Munar, A. M., Jacobsen, J. K. S. 2013. Trust and involvement in tourism social media and webbased travel information sources. Scandinavian Journal of Hospitality and Tourism 13(1), 1-19.

Nezakati, H., Amidi, A., Jusoh, Y. Y., Moghadas, S., Aziz, Y. A., Sohrabinezhadtalemi, R. 2015. Review of social media potential on knowledge sharing and collaboration in tourism industry. Procedia- Social and Behavioural Sciences, 172, 120-125, Elsevier.

O'Reilly, T. 2005. What is Web 2.0. Retrieved from http://www.oreilly.com/pub/a/web2/ archive/what-is-web-20.html

O’Reilly, T. 2006c. Web 2.o Compact Definition: Trying Again. O’Reilly Radar (blog). Dec 1oth 2006. Available online at: http://radar.oreilly.com/archives/2006/12/web 20 compact. $\underline{\mathrm{html}}$

Osei, B. A., Abenyin, A. N. 2016. Applying the Engell-Kollat-Blackwell model in understanding international tourist's use of social media for travel decision to Ghana. Information Technology \& Tourism 16(3), 265-284.

Pan, B., MacLaurin, T., Crotts, J. C. 2007. Travel blogs and the implications for destination marketing. Journal of Travel Research 46(1), 35-45.

$\mathrm{Qu}, \mathrm{H}$., Lee, H. 2011. Travelers' social identification and membership behaviors in online travel community. Tourism management 32(6), 1262-1270.

Rathore, S., Narendran, R. 2019. Understanding the Role of Social Media in Tourist Destination Search and Selection. Journal of Emerging Technology and Innovative Research 6(4), 406-415.

Xiang, Z., Gretzel, U. 2010. Role of social media in online travel information search. Tourism management 31, 179-188.

Zarrad, H., Debabi, M. 2015. Analyzing the Effect of Electronic Word of Mouth on Tourist's Attitude toward Destination and Travel Intention. International Research Journal of Social Science 4(4), 53-6o.

Zeng, B. 2013. Social Media in Tourism. Journal of Tourism E Hospitality 2(1), 125.

Zivkovic, R., Gajic, J., Brdar, I. 2014. The Impact of Social Media on Tourism, Singidunum University, International scientific conference impact of internet on business activities in serbia and worldwide, 758- 761. https://bib.irb.hr/datoteka/783662. Sinteza-2014. pdf\#page $=776$ 